\title{
EVALUATION OF TRACE ELEMENT SUPPLEMENTATION FOR METHANE PRODUCTION AND ECOTOXICOLOGICAL ASPECTS OF SUGAR BEET PRESSED PULP
}

\author{
SZABÓ, P. ${ }^{*}$ - HyBSKÁ, H. ${ }^{2}$ - VARGA, B. B. ${ }^{3}-$ PÓTI, P. ${ }^{4}-$ KÖLES, P. ${ }^{5}-$ RÉTfAlVI, T. ${ }^{1}$ \\ ${ }^{1}$ Institute of Chemistry, Faculty of Forestry, University of Sopron \\ Bajcsy-Zs. 4., H-9400 Sopron, Hungary \\ ${ }^{2}$ Department of Environmental Engineering, Faculty of Ecology and Environmental Sciences, \\ Technical University in Zvolen, T. G. Masaryka 24, 96001 Zvolen, Slovakia \\ ${ }^{3}$ Institute of Environmental and Soil Sciences, Faculty of Forestry, University of Sopron \\ Bajcsy-Zs. 4., H-9400 Sopron, Hungary \\ ${ }^{4}$ Institute of Animal Science and Animal Husbandry, Faculty of Agriculture and Environmental \\ Sciences, Szent István University, Páter Károly 1., H-2100 Gödöllö, Hungary \\ ${ }^{5}$ University of Sopron, Bajcsy-Zs. 4., H-9400 Sopron, Hungary \\ *Corresponding author \\ e-mail: szabo.piroska@uni-sopron.hu; phone: +36-99-518-175 \\ (Received $28^{\text {th }}$ Nov 2017; accepted $20^{\text {th }}$ Feb 2018)
}

\begin{abstract}
The aim of this study was to evaluate the effects of trace element supplementation on semicontinuous anaerobic digestion processes of sugar beet pressed pulp. We also investigated the phytotoxicity of anaerobic sludge via an ecotoxicological test for white mustard (Sinapis alba) and spring barley (Hordeum vulgare L.). To determine the accumulation of microelements, the spring barley test was followed by microelement analysis of sludge, soil and barley biomass samples. The results show that average values of specific methane yields were 11.0 and $11.7 \%$ higher in the supplemented and supplemented plus iron trials compared to the non-supplemented trial, respectively.

In the root elongation test of white mustard, the highest stimulation rate $(-59.41 \%)$ was observed for the 10 -fold dilution in the treatment with trace element and iron supplementation. We observed major stimulation of spring barley biomass production in all trials, with the strongest effect (stimulation of $62.80 \%$ ) in the trace element supplementation plus iron trial. In sludge samples, cobalt levels increased by 14 and 16 times, nickel by 10 and 14 times, boron by 1.8 and 1.9 times, iron by 1.6 and 2.1 times, respectively, in the supplemented and supplemented $+\mathrm{Fe}$ trials. The bioaccumulation factors of different elements varied widely $(0.07-110.8)$.
\end{abstract}

Keywords: anaerobic sludge, microelement, phytotoxicity, Sinapis alba, Hordeum vulgare

\section{Introduction}

The use of sugar beet pressed pulp (SBPP) in anaerobic digestion is one way to abrogate sugar production waste (Tukacs-Hájos et al., 2014). The obtained renewable energy can be applied for heat or electricity production, but there is a secondary derivative, such as fermented sludge, which has a great potential in the application on agricultural and forestry fields for fertilisation (Govasmark et al., 2011; Demirel et al., 2013; Dong et al., 2013). By this complex use we can nearly reach a waste-free technology.

The digester effluents could provide the essential nutrients for plant growth when used as organic fertilisers (Achiba et al., 2010). Since sludges are complex mixtures of 
different substances, speciation of toxic materials would be expected to increase or reduce toxicity (Gómez et al., 2001; García-Delgado et al., 2007; Tu et al., 2012; Li et al., 2010). Effluents used for irrigation water may cause a risk of decreasing crop production due to high salinity (Ullman and Mukhtar, 2007).

Optimal anaerobic digestion can be reached by addition of different trace elements based on to microbial requirements (Zhang and Jang, 2012; Qiang et al., 2013). The most commonly studied elements are iron, cobalt and nickel (Choong et al., 2016). Apart from the positive impact on methane production, the accumulated heavy metals in the sludge could have adverse effects on the soil ecosystem (Walter et al., 2006; Salazar et al., 2012). This negative effect can be prevalent for soil flora and fauna (Carbonell et al., 2009). The most critical point of view is the availability of microelements by plants from the soil, which could be affected by anaerobic digestion and lower mobility of metals from digested slurry (Marcato et al., 2009; Pagnanelli et al., 2009). Zhu et al. (2014) state that $\mathrm{Cu}, \mathrm{Zn}, \mathrm{Mn}, \mathrm{Ni}$ and $\mathrm{Cd}$ may be grouped as toxic and active components in sludge. The different trace elements can appear in food chain systems through cultivated plants from contaminated soil (Wahsha et al., 2014; Le et al., 2015).

Information on the phytoavailability changes with trace element supplementation of anaerobic sludge are scarce. There are two main methods to assess bioavailability: chemical measurements in the soil matrix and biological measurements using organisms exposed to soil (Walsh et al., 1991; Harmsen, 2007). To investigate the injurious effects, different acute and chronic ecotoxicological tests are applied in practise (Rosa et al., 2007; Roig et al., 2012; Young et al., 2012). Lactuca sativa seed germination and root elongation inhibition tests are used for assessing the toxicity reduction from anaerobic digestion based on measuring main chemical operational parameters (Young et al., 2012). Hybská et al. (2017) examined the ecotoxicological properties of granulated slag from the pilot production of gray iron with red mud addition and concrete composites with the application of this slag by testing highly-cultivated plant Sinapis alba. Their results confirmed that the application of the hazardous waste in the production of gray iron produced waste slag with no toxic properties.

The main aims of this study were to investigate the improved methane yield by supplementation of trace elements and to evaluate the ecotoxicological effects on fermented sludge in the application of nutrient replacement for soils.

The biological approach consisted of microelement uptake assessment in growth chamber experiments with spring barley.

\section{Materials and methods}

\section{Anaerobic digestion}

\section{Biogas reactors}

The anaerobic digesters were $1-\mathrm{L}$ working volume bottles $(2.5 \mathrm{~L}$ capacity threaded brown bottles, Merck, Germany). The digesters were incubated in a water bath (Memmert WNB 14 Basic, Memmert GmbH. \& Co.) at a constant temperature of $38^{\circ} \mathrm{C}$. The anaerobic digester inoculum was active, adapted to sugar beet pressed pulp substrate (HRT 20 days) obtained from a biogas plant (Sugar factory, Kaposvár, Hungary). The reactors were manually mixed three times per day and the produced biogas was collected by Tedlar ${ }^{\circledR}$ gas sampling bags; volume was measured with a 
Hamilton gas-tight syringe (Sigma Aldrich Co). Biogas and methane yields were recalculated to the standard conditions for pressure and temperature.

\section{Experimental design}

Sugar beet pressed pulp as substrate was applied in our semi-continuous lab-scale experiments. The organic loading rate was raised to $5.2 \mathrm{gVSL}^{-1} \mathrm{~d}^{-1}$ by day 19 ; subsequently, because of the high tVFA concentration in all trials (up to $10000 \mathrm{mg} \mathrm{L}^{-1}$ ), feeding was stopped for two days. After this, a moderate loading rate was performed from day 22 to day 44 , with a maximum of $3.8 \mathrm{gVSL}^{-1} \mathrm{~d}^{-1}$; subsequently, the organic loading rate (OLR) remained stable until day 81 .

Three parallel reactors were run in all cases of non-supplemented (without trace element supplementation), supplemented $\left(2 \mu \mathrm{L} \mathrm{L}^{-1} \mathrm{~d}^{-1}\right.$ of trace element solution) and supplemented $+\mathrm{Fe}\left(2 \mu \mathrm{L} \mathrm{L}^{-1} \mathrm{~d}^{-1}\right.$ of trace element solution $+82 \mu \mathrm{LL}^{-1} \mathrm{~d}^{-1}$ of $\mathrm{Fe}(\mathrm{III})-$ chloride $40 \%$ aqueous solution - technical grade). The application of high doses of iron is explained by its detoxification effect on sulphide inhibition, as described by (Gonzalez-Silva et al., 2009).

The trace element supplement solution contained $1625 \mathrm{mg}$ of zinc, $13640 \mathrm{mg}$ of manganese, $93 \mathrm{mg}$ of boron, $20000 \mathrm{mg}$ of nickel, $600 \mathrm{mg}$ of copper, $50000 \mathrm{mg}$ of cobalt, $228 \mathrm{mg}$ of molybdenum and $113 \mathrm{mg}$ of selenium in a special organic complex form per $\mathrm{kg}$ of solution (42.2\% TS). Dosing of microelements was based on our former experiment (Tukacs-Hájos et al., 2014).

\section{Analytical methods}

Sludge samples $(10 \mathrm{~mL})$ were taken for chemical analysis before feeding. Samples were centrifuged for $10 \mathrm{~min}$ at $3420 \mathrm{RCF}$ (EBA 21, A. Hettich Co, Germany). From the resulting supernatant, $5 \mathrm{~mL}$ were used for determination of titrated VFA (tVFA) levels (every $5^{\text {th }}$ day), using a potentiometric pH meter (EuTech PC 510, Thermo Fisher Scientific), and calculated in acetic acid equivalents (Rétfalvi et al., 2011).

The components of biogas were analysed using an Ecoprobe 5-IR (RS Dynamics Ltd, Czech Republic).

Determination of COD was carried out according to the Hungarian standard protocol (MSZ ISO 6060). Determination of ammonium and total phosphorus was carried out according to the Hungarian standard protocols MSZ ISO 7150-1 and MSZ 488/18-77, respectively (Rétfalvi et al., 2015).

\section{Ecotoxicological tests}

\section{Preparation of aqueous extracts}

The quantities of original sludges were weighted, corresponding to $100 \pm 0.1 \mathrm{~g}$ of dry matter, and $1 \mathrm{~L}$ of demineralised water was added. Subsequently, the samples were shaken for $6 \mathrm{~h}$. The extracts were then left for $18 \mathrm{~h}$ to sediment and after sedimentation, solid phases were separated by filtration through a paper filter with a pore size of $3 \pm 2 \mu \mathrm{m}$.

\section{Root elongation test with white mustard}

The acute toxicity test was applied according to the Slovakian standard of STN 83 8303:1999. The tested organism was white mustard (Sinapis alba), a member of the Brassicaceae family. The sorted white mustard seeds were ochre-yellow, with a size of 
1.5 to $2.5 \mathrm{~mm}$, and germination power was higher than $99 \%$. Thirty seeds were placed uniformly into Petri dishes (diameter of 120 to $140 \mathrm{~mm}$ ) and $10 \mathrm{~mL}$ of the prepared aqueous extracts were added (Table 1).

Three parallel tests were applied in all dilution rates (dilution of 10, 50, 100 and $200 \mathrm{x}$ ) of non-supplemented, supplemented and supplemented + Fe sludges, respectively.

As diluent, water stock solutions of salts were prepared and also used for the control. The $\mathrm{pH}$ of the diluent water varied around 7.6-8.0.

Table 1. Test conditions of white mustard root growth inhibition

\begin{tabular}{c|c}
\hline Testing organism & $\begin{array}{c}\text { Sinapis alba, ochre yellow, size } 1.5-2 \mathrm{~mm} \text {, germination }>99 \%, 30 \text { seeds in } \\
\text { Petri dish, } 10 \mathrm{~mL} \text { sample }\end{array}$ \\
\hline Temperature & $20 \pm 1{ }^{\circ} \mathrm{C}$, incubator TS $606 \mathrm{CZ} / 2$-Var (WTW, Germany) \\
\hline Control & Reconstituted water \\
\hline Exposition period & 72 hours \\
\hline Monitored response & Root growth inhibition compared to control, IC \\
\hline
\end{tabular}

The basis of inhibition/stimulation effect on root growth was the average length of root determined in the individual concentrations of sludge in comparison with the average root length in the control.

The inhibition-stimulation effect (IC\%) on root growth was calculated using the following equation:

$$
I C \%=\frac{L_{k}-L_{v}}{L_{k}} \cdot 100
$$

where

$\mathrm{L}_{\mathrm{v}}$ is the average length of root in the tested concentration of aqueous sludges in $\mathrm{cm}$,

$\mathrm{L}_{\mathrm{k}}$ is the average length of root in the control in $\mathrm{cm}$.

\section{Spring barley}

The effect of microelement accumulation on terrestrial flora was tested using the Slovakian standard STN EN 14735:2006-03 (83 8300). The static acute toxicity test was designed for investigation of spring barley (Hordeum vulgare L.) biomass in a growth chamber experiment; the germination power of seeds was higher than $97 \%$ (Table 2).

Table 2. Conditions of spring barley static acute toxicity test

\begin{tabular}{c|c}
\hline Testing organism & Hordeum vulgare L., germination $>97 \%$, six seeds in pots, artificial soil mixture \\
\hline Temperature & $22 \pm 1{ }^{\circ} \mathrm{C}$ \\
\hline Humidity & $28-30 \%$, HH2 Moisture Meter (Delta-T Devices of Cambridge, England) \\
\hline Control & Distilled water \\
\hline Exposition period & 21 days \\
\hline Monitored response & Grown biomass, trace element accumulation \\
\hline
\end{tabular}


The experiment was carried out in pots filled with $500 \mathrm{~g}$ of artificial soil mixture of $10 \%$ peat, $20 \%$ kaolin clay and $70 \%$ industrial quartz sand. The soil was irrigated with aqueous extracts and control samples were watered with distilled water; subsequently, six spring barley seeds were planted into each pot.

The controlled conditions were: constant temperature of $22^{\circ} \mathrm{C}$ and constant humidity of $28-30 \%$, which was ensured by daily measurement with a $\mathrm{HH} 2$ Moisture Meter (Delta-T Devices of Cambridge, England) hygrometer.

After an incubation time of 21 days, the grown biomass was weighted for the inhibition-stimulation test and dried for trace element analysis.

\section{Trace element analysis}

Air-dried soil and sludge samples were ground, sieved through a 2-mm sieve, dried at $105{ }^{\circ} \mathrm{C}$ and ground in a mortar. The plant samples were also dried at $105{ }^{\circ} \mathrm{C}$ and ground in a mortar. About $1 \mathrm{~g}$ of each sample was measured in a Teflon bomb and we added $5 \mathrm{~mL} \mathrm{cc} \mathrm{HNO}_{3}$ and $2 \mathrm{~mL} \mathrm{H}_{2} \mathrm{O}_{2}(30 \% \mathrm{~m} / \mathrm{m})$. During the digestion period of $3 \mathrm{~h}$, the bombs were kept in an oven at $110{ }^{\circ} \mathrm{C}$. After filtration, the supernatants were acidified with cc HNO3 and filtrated again. Subsequently, $50 \mathrm{ml}$ of supernatant were evaporated, followed by adding $1 \mathrm{ml} \mathrm{cc} \mathrm{HNO}_{3}$ and washing into a 25-ml volumetric flask. Elemental analysis was carried out by ICP-OES (iCAP 6300 Duo ICP-OES, Thermo Fisher Scientific Inc, Waltham, MA USA).

\section{Statistical analysis}

The software package STATISTICA 10 (Version 10, StatSoft, Tulsa, OK, USA) was used for performing (analysis of variance) and single factor dispersion analysis to evaluate the results of the ecotoxicological tests. Graphical presentation of ANOVA and Duncan's test results was performed using 95\% confidence intervals for average immobilisation and inhibition values for individual samples (Hybská et al., 2017).

\section{Results and discussion}

\section{Methane production}

The effect of microelement supplementation was examined via methane production (Fig. 1) The average values of specific methane yield (SMY) $\left(403.8 \pm 4.51^{\mathrm{a}} \mathrm{mL} \mathrm{CH}_{4}\right.$ $\mathrm{gVS}^{-1}$ in case of non-supplemented, $448.3 \pm 9.91^{\mathrm{b}} \mathrm{mL} \mathrm{CH} \mathrm{gVS}^{-1}$ in case of supplemented and $451.1 \pm 9.16^{\mathrm{b}} \mathrm{mL} \mathrm{CH}_{4} \mathrm{gVS}^{-1}$ in case of supplemented $+\mathrm{Fe}$ trial, different letters indicate significant difference at $\mathrm{P} \leq 0.05$ ) represent the $11.0 \%$ and $11.7 \%$ benefit effect of supplementations. This observation is in agreement with the findings of Wall et al. (2014). They reported an increase in SMY in the mono-digestion of grass-silage by $12 \%$ to $404 \mathrm{~L} \mathrm{CH}_{4} \mathrm{~kg}^{-1} \mathrm{VS}$ by the effects of $\mathrm{Co}, \mathrm{Fe}$ and Ni addition. The specific methane yields were balanced during the uploading stage, with average values being 285.2, 317.6 and $328.9 \mathrm{~mL} \mathrm{CH}_{4} \mathrm{~g} \mathrm{VS}^{-1}$ for the non-supplemented, supplemented and supplemented + Fe trial, respectively (Fig. 1). Values of the average SMY values of supplemented and supplemented + Fe compared to non-supplemented increased by 12.6 and $23.0 \%$ during the drastic overloading period (day 12-19). The most significant effect of microelement supplementation on SMY was recognised during the reloading stage. In the first seven days of this period, SMY values increased by 22.2 and $32.3 \%$ and then decreased by 6.5 and $29.3 \%$ in the supplemented 
fermenters. During the stable run at moderate OLR levels, the effects of microelement supplementation on SMY rates were lower (5.8 and 1.8\%, respectively).

The methane content of biogas was not significantly influenced by microelement supplementation. Average methane values and ranges of daily biogas production were 53.95 (51.68-56.74\%), 54.19 (51.66-58.32\%) and 53.49\% (50.36-58.69\%) for the nonsupplemented, supplemented and supplemented + Fe trial, respectively.

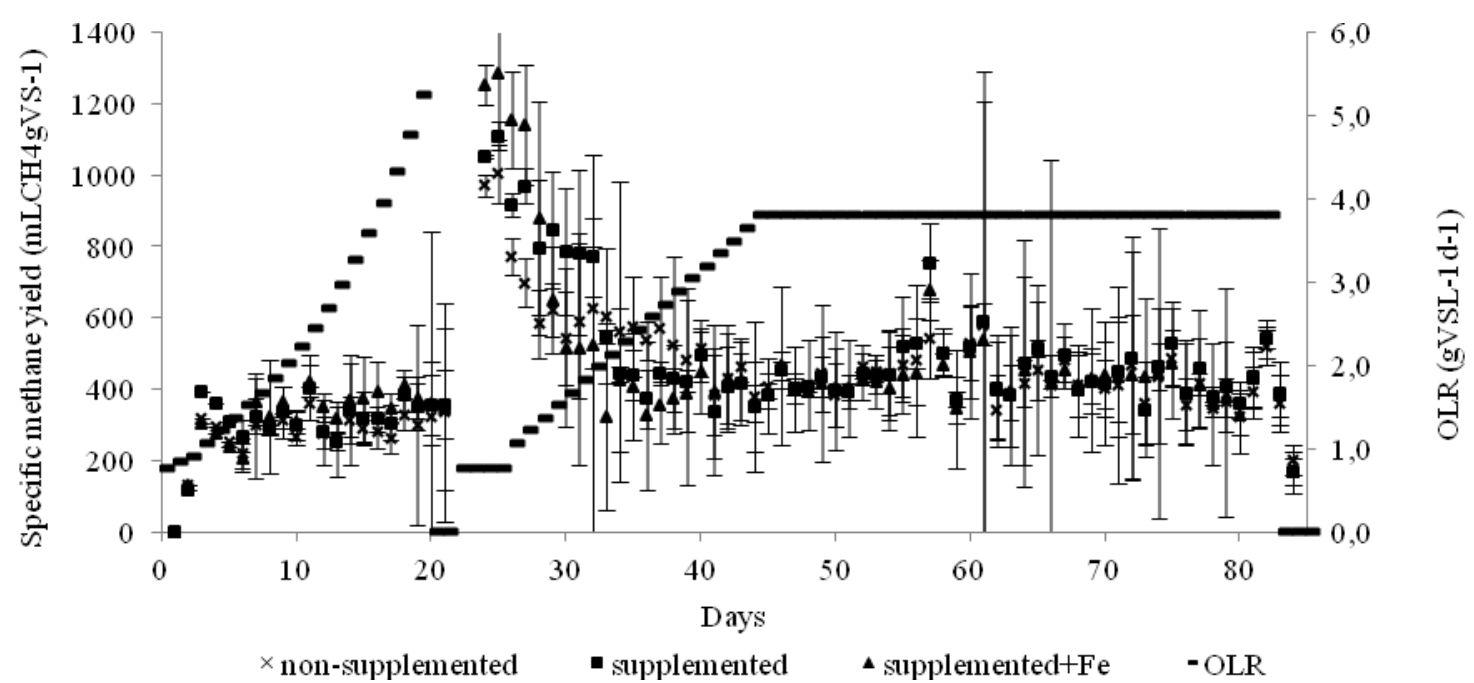

Figure 1. Alteration of specific methane yields of non-supplemented, supplemented and supplemented $+\mathrm{Fe}$ trials during the experiment

The initial tVFA level of the sludge was $2440 \mathrm{mg} \mathrm{L}^{-1}$. By increasing the OLR rate, the tVFA levels raised, but remained under $4500 \mathrm{mg} \mathrm{L}^{-1}$ during the first 1 days of the experiment in all cases. On day 20 at $5.2 \mathrm{~g} \mathrm{VSL}^{-1} \mathrm{~d}^{-1}$, OLR average and standard deviation of tVFA levels increased to $12496 \pm 1452 \mathrm{mg} \mathrm{L}^{-1}, 11421 \pm 917 \mathrm{mg} \mathrm{L}^{-1}$, $9943 \pm 1211 \mathrm{mg} \mathrm{L}^{-1}$ in the non-supplemented, supplemented and supplemented $+\mathrm{Fe}$ trial, respectively. Based on the effect of interrupted OLR, acid levels decreased by $12.9,21.2$ and $17.6 \%$, respectively, thus moderate uploading (constant $0.76 \mathrm{gVSL}^{-1} \mathrm{~d}^{-1}$ for four days, then increasing up to $3.80 \mathrm{~g} \mathrm{VSL}^{-1} \mathrm{~d}^{-1}$ in the 19-day period) was started at day 22. Before reaching a stable run period, tVFA levels decreased rapidly by 58.1, 69.4 and $70.3 \%$, respectively, by day 30 of the experiment. Until the end of the experiment, tVFA concentrations remained at low levels of $2500-3000 \mathrm{mg} \mathrm{L}^{-1}$ in all cases. Similar effects of microelement supplementation were described in the study of Qiang et al. (2013), who found that at $6.3 \mathrm{~kg} \mathrm{~m}^{-3} \mathrm{~d}^{-1}$ OLR level of high-solid food waste, the addition of $10 \mathrm{mg} \mathrm{L}^{-1} \mathrm{Fe}^{2+}, 1 \mathrm{mg} \mathrm{L}^{-1} \mathrm{Co}^{2+}$ and $1 \mathrm{mg} \mathrm{L}^{-1} \mathrm{Ni}^{2+}$, approximately every 45 days, resulted in efficient methane fermentation. A comparison of our microelement supplementation level with the above-mentioned date is not relevant due to the different bioavailability of the chelate-form and inorganic ions.

The most relevant chemical parameters (COD, soluble $\mathrm{NH}_{4}{ }^{+}$and total $\mathrm{P}$ ) of the sludges were determined every two weeks during the experiments; no significant difference was found between the groups. Average values of sludge COD, $\mathrm{NH}_{4}{ }^{+}$and total P used for ecotoxicological experiments were $4920 \pm 173 \mathrm{mg} \mathrm{L}^{-1}, 1457 \pm 106 \mathrm{mg}$ $\mathrm{L}^{-1}$ and $40 \pm 4 \mathrm{mg} \mathrm{L}^{-1} ; 5104 \pm 147 \mathrm{mg} \mathrm{L}^{-1}, 1422 \pm 93 \mathrm{mg} \mathrm{L}^{-1}$ and $36 \pm 4 \mathrm{mg} \mathrm{L}^{-1} ; 5157$ 
$\pm 214 \mathrm{mg} \mathrm{L}^{-1}, 1349 \pm 71 \mathrm{mg} \mathrm{L}^{-1}$ and $35 \pm 2 \mathrm{mg} \mathrm{L}^{-1}$ in the non-supplemented, supplemented and supplemented $+\mathrm{Fe}$ trials, respectively.

Zhang and Jahng (2012) reported the essential role of iron in the long-term anaerobic digestion of food waste. They found that the operational parameters $\left(\mathrm{CH}_{4}\right.$ yield, $\mathrm{pH}$ value, tVFA concentration) of anaerobic digestion of food waste remained stable in a year-long experiment in the case of microelement ( $\mathrm{Co}, \mathrm{Mo}, \mathrm{Ni}, \mathrm{Fe})$ supplementation. Contrary to our results, they did not find increasing SMY levels with microelement supplementation.

\section{Ecotoxicological tests}

\section{Root elongation test with white mustard}

A decreased inhibitory effect could be determined in the non-supplemented treatment with increasing dilution rates (Fig. 2). The highest stimulating rate $(-59.41 \%)$ was found for a 10 -fold dilution in the supplemented + Fe trial. Iron completion had no significant effect on IC\% values.

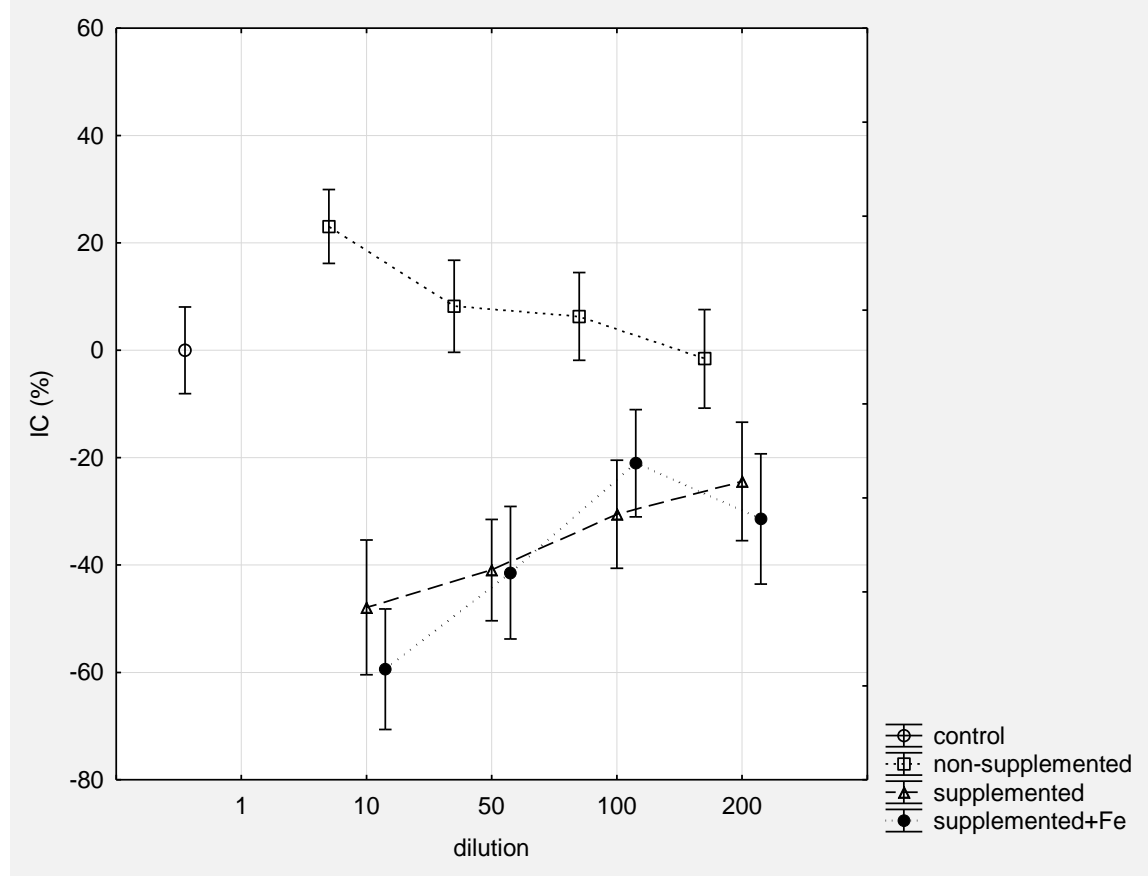

Figure 2. Effects of dilution rates of anaerobic sludge on root growth of white mustard (0-100 IC\%: inhibition, 0-100 IC\%: stimulation)

The preliminary test was negative as root growth inhibition was less than $30 \%$ and stimulation was lower than $75 \%$ compared to the control; therefore, further tests were not necessary (STN 83 8303:1999).

To correct the two-sample t-test, which, if used in more couples, would produce incorrect results, Duncan's probability of equality test was used. Based on the results in Table 3, the difference between control and non-supplemented (50 x dilutions) was $28.7 \%$, while the difference between control and non-supplemented (100 x dilution) was $38.2 \%$ and that between control and non-supplemented (100 x dilution) was $82.6 \%$. All other dilution combinations and samples were significantly different from the control. 
Table 3. Confidence levels for Duncan's test - P-value for Duncan's test and for the root growth inhibition test in Sinapis alba

\begin{tabular}{c|c|c|c|c|c|c|c|c|c|c|c|c|c|c|c}
\hline Sample & & Control & $\begin{array}{c}\text { Non- } \\
\text { suppl. }\end{array}$ & $\begin{array}{c}\text { Non- } \\
\text { suppl. }\end{array}$ & $\begin{array}{c}\text { Non- } \\
\text { suppl. }\end{array}$ & $\begin{array}{c}\text { Non- } \\
\text { suppl. }\end{array}$ & Suppl. & Suppl. & Suppl. & Suppl. & Suppl.+Fe & Suppl.+Fe & Suppl.+Fe & Suppl.+Fe \\
\cline { 2 - 14 } & Dilution & 1 & 10 & 50 & 100 & 200 & 10 & 50 & 100 & 200 & 10 & 50 & 100 & 200 \\
\hline Control & 1 & 0 & 23.07 & 8.196 & 6.296 & -1.583 & -30.53 & -24.41 & -40.94 & -47.87 & -59.41 & -41.44 & -21.03 & -31.41 \\
\hline $\begin{array}{c}\text { Non- } \\
\text { suppl. }\end{array}$ & 10 & 0.002 & & 0.002 & 0.287 & 0.382 & 0.826 & 0.000 & 0.001 & 0.000 & 0.000 & 0.000 & 0.000 & 0.005 & 0.000 \\
\hline $\begin{array}{c}\text { Non- } \\
\text { suppl. }\end{array}$ & 50 & 0.287 & 0.039 & & 0.026 & 0.001 & 0.000 & 0.000 & 0.000 & 0.000 & 0.000 & 0.000 & 0.000 & 0.000 \\
\hline $\begin{array}{c}\text { Non- } \\
\text { suppl. }\end{array}$ & 100 & 0.382 & 0.026 & 0.792 & 0.221 & 0.000 & 0.000 & 0.000 & 0.000 & 0.000 & 0.000 & 0.000 & 0.000 \\
\hline $\begin{array}{c}\text { Non- } \\
\text { suppl. }\end{array}$ & 200 & 0.826 & 0.001 & 0.221 & 0.306 & & 0.000 & 0.002 & 0.000 & 0.000 & 0.000 & 0.000 & 0.007 & 0.000 \\
\hline Suppl. & 10 & 0.000 & 0.000 & 0.000 & 0.000 & 0.000 & & 0.396 & 0.174 & 0.030 & 0.000 & 0.171 & 0.216 & 0.903 \\
\hline Suppl. & 50 & 0.001 & 0.000 & 0.000 & 0.000 & 0.002 & 0.396 & & 0.034 & 0.003 & 0.000 & 0.033 & 0.639 & 0.364 \\
\hline Suppl. & 100 & 0.000 & 0.000 & 0.000 & 0.000 & 0.000 & 0.174 & 0.034 & & 0.368 & 0.017 & 0.946 & 0.012 & 0.186 \\
\hline Suppl. & 200 & 0.000 & 0.000 & 0.000 & 0.000 & 0.000 & 0.030 & 0.003 & 0.368 & & 0.109 & 0.372 & 0.001 & 0.035 \\
\hline $\begin{array}{c}\text { Suppl. + } \\
\text { Fe }\end{array}$ & 10 & 0.000 & 0.000 & 0.000 & 0.000 & 0.000 & 0.000 & 0.000 & 0.017 & 0.109 & & 0.017 & 0.000 & 0.000 \\
\hline $\begin{array}{c}\text { Suppl. + } \\
\text { Fe }\end{array}$ & 50 & 0.000 & 0.000 & 0.000 & 0.000 & 0.000 & 0.171 & 0.033 & 0.946 & 0.372 & 0.017 & & 0.011 & 0.191 \\
\hline $\begin{array}{c}\text { Suppl. + } \\
\text { Fe }\end{array}$ & 100 & 0.005 & 0.000 & 0.000 & 0.000 & 0.007 & 0.216 & 0.639 & 0.012 & 0.001 & 0.000 & 0.011 & & 0.193 \\
\hline $\begin{array}{c}\text { Suppl. + } \\
\text { Fe }\end{array}$ & 200 & 0.000 & 0.000 & 0.000 & 0.000 & 0.000 & 0.903 & 0.364 & 0.186 & 0.035 & 0.000 & 0.191 & 0.193 & \\
\hline
\end{tabular}

\section{Spring barley}

The effect of trace element supplementation of anaerobic sludge was studied using the static acute toxicity test for spring barley. There was no inhibition on grown biomass, and a major stimulation on biomass production was observed in all trials. The stimulation ratio increased with supplementation; the strongest effect (stimulation of $62.80 \%$ ) was determined in the case of supplementation with iron, as shown in Table 4. Iron is a part of the active groups of enzymes and involved in many physiological processes. The most important process is the formation of chlorophyll, which is a photosynthetically active dye. In our study, supplementation affected net assimilation rate and thus the amount of biomass produced. Regarding to the results of biomass production based on Duncan's probability test, equality of samples different significantly from the control and between the pairs of samples, respectively.

Table 4. Stimulation effects of anaerobic sludge on biomass production of spring barley ( 0 100 IC\%: inhibition, 0-100 IC\%: stimulation)

\begin{tabular}{c|c|c|c|c}
\hline \multirow{2}{*}{ Sample } & \multicolumn{4}{|c}{ Stimulation (\%) } \\
\cline { 2 - 5 } & Average & Standard deviation & $\mathbf{- 9 5 . 0 0 \%}$ & $\mathbf{9 5 . 0 0 \%}$ \\
\hline Non-supplemented & -10.17 & 0.12 & 9.65 & 10.68 \\
\hline Supplemented & -26.37 & 0.27 & 25.22 & 27.51 \\
\hline Supplemented + Fe & -62.80 & 0.76 & 59.54 & 66.06 \\
\hline
\end{tabular}


Our results partly contradict by the findings of Roig et al. (2012), who did not observe a correlation between heavy metal contamination and ecotoxicology of different sewage sludges due to the low metal content. They suggested that organic pollutants, such as phenols, have a higher significance than inorganic compounds.

\section{Trace element analysis}

The effect of microelement-enriched anaerobic sludge on element accumulation during the spring barley test was followed by microelement analysis of sludge, soil and barley biomass samples (Table 5). Application of microelement supplementation during anaerobic digestion enhanced element levels in the sludge (Table 5). Cobalt levels increased by 14 and 16 times, nickel by 10 and 14 times, boron by 1.8 and 1.9 times, iron by 1.6 and 2.1 times higher in the supplemented and supplemented $+\mathrm{Fe}$ trial, respectively. Despite zinc supplementation with iron addition, the concentration of zinc decreased by $33 \%$. Interpretation of this phenomenon has not revealed yet. The metal contents of the sludges were significantly lower than those in the study by Roig et al. (2012), considering 10-100 times higher metal concentrations in sewage sludge.

Table 5. Trace element concentrations of sludge, artificial soil and spring barley samples (different letters indicate significant difference at $P \leq 0.05$ )

\begin{tabular}{|c|c|c|c|c|c|c|c|c|c|c|c|c|c|c|c|}
\hline \multicolumn{16}{|c|}{ Trace element concentrations of sludge samples } \\
\hline \multicolumn{2}{|c|}{$\mathrm{Mg} \mathrm{kg} \mathrm{TS}^{-1}$} & $\mathrm{Al}$ & B & $\mathrm{Ba}$ & $\mathrm{Cd}$ & Co & $\mathrm{Cr}$ & $\mathrm{Cu}$ & $\mathrm{Fe}$ & $\mathrm{Li}$ & $\mathrm{Mn}$ & $\mathrm{Ni}$ & $\mathrm{Pb}$ & $\mathrm{Sr}$ & $\mathrm{Zn}$ \\
\hline \multirow{2}{*}{ Non-supp } & Average & 0.26 & $0.61^{\mathrm{a}}$ & $0.14^{\mathrm{a}}$ & n.d. & $\mathbf{0 . 0 3}^{\mathrm{a}}$ & n.d. & $0.06^{\mathrm{a}}$ & $1.95^{\mathrm{a}}$ & $0.01^{\mathrm{a}}$ & $0.37^{\mathrm{a}}$ & $0.03^{\mathrm{a}}$ & $0.01^{\mathrm{a}}$ & $0.64^{\mathrm{a}}$ & $0.45^{\mathrm{a}}$ \\
\hline & SD & .030 & 090 & 010 & - & 0.002 & - & 0.02 & 0.18 & 0.000 & 0.07 & 0.01 & 0.002 & 0.07 & 3 \\
\hline \multirow{2}{*}{ Supp } & Average & n.d. & $1.13^{b}$ & $.10^{\mathrm{a}}$ & n.d. & $0.50^{b}$ & 0.01 & $0.07^{\mathrm{a}}$ & $3.16^{\mathrm{ab}}$ & $0.04^{\mathrm{a}}$ & $0.30^{\mathrm{a}}$ & $0.42^{\mathrm{b}}$ & $0.01^{\mathrm{a}}$ & $0.60^{\mathrm{a}}$ & $0.41^{\mathrm{a}}$ \\
\hline & SD & - & 0.040 & 0.010 & - & 0.110 & 0.002 & 0.01 & 0.46 & 001 & 0.02 & 0.08 & 0.002 & 0.02 & 0.06 \\
\hline \multirow{2}{*}{$\mathrm{Supp}+\mathrm{Fe}$} & Averag & n.d. & $1.15^{\mathrm{b}}$ & $0.08^{\mathrm{a}}$ & n.d. & $0.42^{\mathrm{b}}$ & 0.01 & $0.05^{\mathrm{a}}$ & $4.09^{b}$ & $0.04^{\mathrm{a}}$ & $0.41^{\mathrm{a}}$ & $0.32^{\mathrm{b}}$ & $0.01^{\mathrm{a}}$ & $0.57^{\mathrm{a}}$ & $0.30^{\mathrm{a}}$ \\
\hline & SD & - & 0.040 & 0.020 & - & 0.080 & 0.003 & 0.01 & 0.38 & 0.005 & 0.0 & .0 & 0.001 & 0.20 & 0.08 \\
\hline \multicolumn{16}{|c|}{ Trace element concentrations of artificial soil samples } \\
\hline \multicolumn{2}{|c|}{$\mathrm{Mg} \mathrm{kg} \mathrm{TS}^{-1}$} & $\mathrm{Al}$ & B & $\mathrm{Ba}$ & $\mathrm{Cd}$ & Co & $\mathrm{Cr}$ & $\mathrm{Cu}$ & $\mathrm{Fe}$ & $\mathrm{Li}$ & Mn & $\mathrm{Ni}$ & $\mathrm{Pb}$ & $\mathrm{Sr}$ & $\mathrm{Zn}$ \\
\hline \multirow{2}{*}{ Control } & Average & $2688^{a}$ & $0.94^{\mathrm{a}}$ & $10.8^{\mathrm{a}}$ & $\mathbf{0 . 0 3}^{\mathrm{a}}$ & $1.21^{\mathrm{a}}$ & $4.97^{\mathrm{a}}$ & $3.80^{\mathrm{a}}$ & $3304^{\mathrm{a}}$ & $4.88^{\mathrm{a}}$ & $86.5^{\mathrm{a}}$ & $3.69^{a}$ & $50.0^{\mathrm{a}}$ & $30.8^{\mathrm{a}}$ & $29.8^{\mathrm{a}}$ \\
\hline & SD & 189.4 & 0.099 & 0.505 & 0.007 & 0.145 & 0.425 & 0.245 & 448.1 & 0.020 & 8.655 & 0.193 & 7.566 & 4.701 & 5.940 \\
\hline \multirow{2}{*}{ Non-supp } & Average & $3031^{a}$ & $1.49^{\mathrm{a}}$ & $24.0^{b}$ & $0.02^{\mathrm{a}}$ & $1.96^{\mathrm{a}}$ & $5.19^{\mathrm{a}}$ & $3.31^{\mathrm{a}}$ & $3253^{a}$ & $4.86^{\mathrm{a}}$ & $84.3^{\mathrm{a}}$ & $4.00^{a}$ & $24.6^{\mathrm{a}}$ & $31.5^{\mathrm{a}}$ & $28.3^{\mathrm{a}}$ \\
\hline & SD & 397.2 & 0.223 & 1.310 & 0.009 & 0.296 & 0.667 & 0.463 & 51.13 & 0.086 & 5.579 & 0.320 & 9.851 & 6.496 & 5.561 \\
\hline \multirow{2}{*}{ Supp } & Average & $2533^{a}$ & $3.87^{b}$ & $25.4^{\mathrm{b}}$ & $0.01^{\mathrm{a}}$ & $19.2^{b}$ & $4.17^{\mathrm{a}}$ & $4.81^{b}$ & $2971^{a}$ & $4.86^{\mathrm{a}}$ & $95.1^{\mathrm{a}}$ & $10.5^{b}$ & $33.0^{\mathrm{a}}$ & $31.4^{\mathrm{a}}$ & $30.3^{\mathrm{a}}$ \\
\hline & SD & 109.2 & 0.338 & 1.615 & 0.000 & 0.784 & 0.554 & \begin{tabular}{|l|l|}
0.098 \\
\end{tabular} & 150.3 & 0.011 & 2.980 & 1.386 & 15.31 & 3.032 & 2.044 \\
\hline \multirow{2}{*}{$\mathrm{Supp}+\mathrm{Fe}$} & Average & $3103^{a}$ & $3.17^{b}$ & $35.9^{c}$ & $\mathrm{O.03}^{\mathrm{a}}$ & $13.9^{\mathrm{c}}$ & $4.52^{\mathrm{a}}$ & $4.69^{b}$ & $3484^{\mathrm{a}}$ & $4.71^{\mathrm{a}}$ & $98.9^{a}$ & $9.11^{b}$ & $39.9^{\mathrm{a}}$ & $28.3^{\mathrm{a}}$ & $30.7^{\mathrm{a}}$ \\
\hline & SD & 775.0 & 0.519 & 4.367 & 0.009 & 1.925 & 0.404 & 0.043 & 110.5 & 0.099 & 5.050 & 0.50 & 6.507 & 1.064 & 5.464 \\
\hline \multicolumn{16}{|c|}{ Trace element concentrations of spring barley samples } \\
\hline \multicolumn{2}{|c|}{$\mathrm{Mg} \mathrm{kg} \mathrm{\textrm {TS } ^ { - 1 }}$} & $\mathrm{Al}$ & B & $\mathrm{Ba}$ & $\mathrm{Cd}$ & Co & $\mathrm{Cr}$ & $\mathrm{Cu}$ & $\mathrm{Fe}$ & $\mathrm{Li}$ & $\mathrm{Mn}$ & $\mathrm{Ni}$ & $\mathrm{Pb}$ & $\mathrm{Sr}$ & $\mathrm{Zn}$ \\
\hline \multirow{2}{*}{ ontrol } & Average & $408^{\mathrm{a}}$ & $47.7^{\mathrm{a}}$ & $25.4^{\mathrm{a}}$ & $0.00^{\mathrm{a}}$ & $0.16^{\mathrm{a}}$ & $1.19^{\mathrm{a}}$ & $19.1^{\mathrm{a}}$ & $350^{\mathrm{a}}$ & $2.21^{\mathrm{a}}$ & $105^{\mathrm{a}}$ & $0.69^{\mathrm{a}}$ & $5.76^{\mathrm{a}}$ & $24.2^{\mathrm{a}}$ & $104^{\mathrm{a}}$ \\
\hline & SD & 180.0 & 1.463 & 13.53 & 0.000 & 0.067 & 0.251 & 8.230 & 37.19 & 0.196 & 6.427 & 0.127 & 1.608 & 3.613 & 48.92 \\
\hline \multirow{2}{*}{ Non-supp } & Average & $213^{\mathrm{a}}$ & $53.2^{\mathrm{a}}$ & $17.0^{\mathrm{a}}$ & $0.27^{\mathrm{a}}$ & $0.67^{\mathrm{a}}$ & $0.91^{\mathrm{a}}$ & $10.3^{\mathrm{a}}$ & $249^{a}$ & $2.07^{\mathrm{a}}$ & $66.4^{\mathrm{b}}$ & $1.20^{\mathrm{ab}}$ & $2.48^{\mathrm{a}}$ & $17.2^{\mathrm{b}}$ & $59.0^{\mathrm{a}}$ \\
\hline & SD & 35.37 & 3.374 & 1.908 & 0.151 & 0.020 & 0.028 & 4.669 & 16.17 & 0.228 & 8.187 & 0.511 & 0.851 & 1.036 & 12.89 \\
\hline \multirow{2}{*}{ Supp } & Average & $543^{a}$ & $48.2^{\mathrm{a}}$ & $21.9^{a}$ & $0.13^{a}$ & $3.36^{b}$ & $1.29^{\mathrm{a}}$ & $22.3^{\mathrm{a}}$ & $238^{a}$ & $2.64^{\mathrm{a}}$ & $76.1^{\text {ab }}$ & $1.66^{b}$ & $4.53^{\mathrm{a}}$ & $24.2^{\mathrm{ab}}$ & $84.8^{\mathrm{a}}$ \\
\hline & SD & 187.5 & 29.12 & 6.338 & 0.000 & 0.024 & 0.566 & 2.464 & 76.03 & 0.581 & 3.493 & 0.490 & 3.906 & 4.722 & 15.19 \\
\hline \multirow{2}{*}{$\mathrm{Supp}+\mathrm{Fe}$} & Average & $423^{a}$ & $38.8^{\mathrm{a}}$ & $16.7^{\mathrm{a}}$ & $2.95^{b}$ & $6.35^{\mathrm{c}}$ & $3.77^{\mathrm{b}}$ & $17.7^{\mathrm{a}}$ & $325^{\mathrm{a}}$ & $5.46^{\mathrm{a}}$ & $75.1^{\mathrm{ab}}$ & $3.99^{c}$ & $5.83^{\mathrm{a}}$ & $22.2^{\mathrm{ab}}$ & $77.2^{\mathrm{a}}$ \\
\hline & SD & 144.7 & 0.635 & 0.014 & \begin{tabular}{|l|}
0.563 \\
\end{tabular} & 1.726 & 1.626 & \begin{tabular}{|l|}
0.103 \\
\end{tabular} & 33.28 & 1.342 & 7.504 & 0.749 & 0.289 & 0.135 & 7.025 \\
\hline
\end{tabular}


Similar observations can be found while studying the effect of irrigation with anaerobic sludges on the microelement composition of soil samples (Table 5). Due to the initial high iron content of the soil, sludge amendment did not elevate iron levels. Barium levels were increased through sludges originating from SBPP digestion.

The results obtained in alteration of metals in soil by the effect of sludge amendment are similar to previous study (Carbonell et al., 2009). The amendment of sludges originating from municipal wastewater treatment resulted in significantly higher concentrations of $\mathrm{Zn}$ and $\mathrm{Cu}$ in soils due to the high $\mathrm{Zn}$ and $\mathrm{Cu}$ content of the sludge. No significant difference was observed for $\mathrm{Cd}, \mathrm{Cr}$ and $\mathrm{Ni}$ concentrations.

Bioaccumulation factors (BF) of different elements varied widely (0.07-110.8). Extremely high values were found for cadmium (more than 100 times higher) in the supplemented $+\mathrm{Fe}$ treatment, which were 10 times higher than those in the supplemented or non-supplemented samples. This can be explained by the synergic effect of iron on cadmium accumulation. Similar impacts were found for cobalt and chromium deposition. Microelement supplementation of sludge had a negative effect on boron BF; the accumulation of microelements in spring barley samples is shown in Table 5. Cobalt concentrations increased by 4.2, 21.0 times and 40.0 times in the nonsupplemented, supplemented and supplemented $+\mathrm{Fe}$ trial, respectively. A similar tendency (1.7, 2.4 and 5.8 times higher) was found for nickel. The significant accumulation of cadmium, chrome and lithium in barley samples, observed in the supplementation + Fe trial, cannot be explained by the relevant values of the sludges.

\section{Conclusion}

This study has highlighted the importance of trace element supplementation for anaerobic digestion of SBPP. In addition, we investigated the ecotoxicological effects of sludges on root elongation (white mustard) and accumulation on terrestrial flora (spring barley).

Based on the average values of SMY, supplementation (supplemented and supplemented + iron) increased the values by 11.0 and $11.7 \%$ compared to the nonsupplemented control trial. The methane content of the produced biogas was not significantly influenced by microelement supplementation. This means that anaerobic digestion with trace element supplementation is more stable and flexible, while during an imbalance caused by overload stress, tVFA values remained $9-11 \%$ lower in the supplemented trials compared to the control, indicating that the systems could regenerate faster.

Ecotoxicological assessment of anaerobic sludges is extremely important to determine application possibilities that could adversely affect forestry and agriculture.

The applied tests were appropriate indicators to determine the differences of inhibition-stimulation effects. In the white mustard root elongation test, the highest stimulation rate $(-59.41 \%)$ was found for the 10 -fold dilution in the supplemented + iron trial. The results of static acute toxicity test of spring barley showed that the stimulation ratio increased with supplementation; the strongest effect (stimulation of $-62.80 \%$ ) was determined supplementation with iron. This stimulation effect of sludge originating from SBPP metal-supplemented anaerobic digestion highlights the fact that plantderived sludges have a lower ecotoxicology compared to sludges with high metal contents (Roig et al., 2012). 
Bioaccumulation factors (BF) of microelements in spring barley/soil samples varied widely between 0.07 and 110.8. According to the results of the sludge trace element analysis, irrigation of barley with sludge impacts soil metal concentrations. Therefore, additional physico-chemical and microbiological data should also be considered in order to better understand the long-term implications of plant-derived anaerobic sludge addition to forest and agricultural soils.

Acknowledgements. The project was supported by the ÚNKP-16-3-1 "New National Excellence Program of the Ministry of Human Capacities" Hungary, by the Slovak Grant Agency VEGA 1/0377/17 "Research on the synergistic effects of noise interference and ecototoxic effects Substances in hazardous plants of forestry and wood-processing enterprises", and by VKSZ_12-1-2013-0034 projects.

\section{REFERENCES}

[1] Achiba, W. B., Lakhdar, A., Gabteni, N., Laing, G. D., Verloo, M., Boeckx, P., Cleemput, O. V. (2010): Accumulation and fractionation of trace metals in a Tunisian calcareous soil amended with farm yard manure and municipal solid waste compost. - J. Hazard. Mater. 176: 99-108.

[2] Carbonell, G., Pro, J., Gómez, N., Babín, M. M., Fernández, C., Alonso, E., Tarazona, J. V. (2009): Sewage sludge applied to agricultural soil: Ecotoxicological effects on representative soil organisms. - Ecotox. Environ. Safe. 72: 1309-1319.

[3] Choong, Y. Y., Norli, I., Abdullah, A. Z., Yhaya, M. F. (2016): Impacts of trace element supplementation on the performance of anaerobic digestion process: A critical review. Biores. Technol. 209: 369-379.

[4] Demirel, B., Göl, N. P., Onay, T. T. (2013): Evaluation of heavy metal content in digestate from batch anaerobic co-digestion of sunflower hulls and poultry manure. $-\mathrm{J}$. Mater. Cycles Waste Manage. 15: 242-246.

[5] Dong, B., Liu, X. G., Dai, L. L., Dai, X. H. (2013): Changes of heavy metal speciation during high-solid anaerobic digestion of sewage sludge. - Bioresour. Technol. 131: 152158.

[6] García-Delgado, M., Rodríguez-Cruz, M. S., Lorenzo, L. F., Arienzo, M., SánchezMartín, M. J. (2007): Seasonal and time variability of heavy metal content and of its chemical forms in sewage sludges from different wastewater treatment plants. - Sci. Total Environ. 382: 82-92.

[7] Gómez, C., Contento, L., Carsen, A. (2001): Toxicity test to assess pollutants removal during wastewater treatment and the quality of receiving waters in Argentina. - Environ. Toxicol. 16: 217-224.

[8] Gonzalez-Silva, B. M., Briones-Gallardo, R., Razo-Flores, E., Celis, L. B. (2009): Inhibition on sulfate-reduction by iron, cadmium and sulfide in granular sludge. - J. Hazard. Mater. 172: 400-407.

[9] Govasmark, E., Stäb, J., Holen, B., Hoornstra, D., Nesbakk, T., Salkinoja-Salonen, M. (2011): Chemical and microbiological hazards associated with recycling of anaerobic digested residue intended for agricultural use. - Waste Manage. 31: 2577-2583.

[10] Harmsen, J. (2007): Measuring bioavailability: from a scientific approach to standard methods. - J. Environ. Qual. 36: 1420-1428.

[11] Hybská, H., Hroncová, E., Ladomerský, J., Balco, K., Mitterpach, J. (2017): Ecotoxicity of concretes with granulated slag from gray iron pilot production as filler. - Materials 10: $505-516$.

[12] Le, T. T. Y., Swartjes, F., Römkens, P., Groenenberg, J. E., Wang, P., Lofts, S., Hendriks, A. J. (2015): Modelling metal accumulation using humic acid as a surrogate for plant roots. - Chemosphere 124: 61-69. 
[13] Li, Y. X., Xiong, X., Lin, C. Y., Zhang, F. S., Li, W., Han, W. (2010): Cadmium in animal production and its potential hazard on Beijing and Fuxin farmlands. - J. Hazard. Mater. 1-3: 475-480.

[14] Marcato, C. E., Pinelli, E., Cecchi, M., Winterton, P., Guiresse, M. (2009): Bioavailability of $\mathrm{Cu}$ and $\mathrm{Zn}$ in raw and anaerobically digested pig slurry. - Ecotox. Environ. Safe. 72: 1538-1544.

[15] Pagnanelli, F., Mainelli, S., Bornoroni, L., Dionisi, D., Toro, L. (2009): Mechanisms of heavy-metal removal by activated sludge. - Chemosphere 75: 1028-1034.

[16] Qiang, H., Niu, Q., Chi, Y., Li, Y. (2013): Trace metals requirements for continuous thermophilic methane fermentation of high-solid food waste. - Chem. Eng. J. 223: 330336.

[17] Rétfalvi, T, Tukacs-Hájos, A, Albert, L, Marosvölgyi, B. (2011): Laboratory scale examination of the effects of overloading on the anaerobic digestion by glycerol. Bioresour. Technol. 102: 5270-5275.

[18] Rétfalvi, T., Szabó, P., Tukacs-Hájos, A., Albert, L., Kovács, A., Milics, G., Neményi, M., Lakatos, E., Ördög, V. (2015): Effect of co-substrate feeding on methane yield of anaerobic digestion of Chlorella vulgaris. - Journal of Applied Phycology 28(5): 27412752.

[19] Roig, N., Jordi, Sierra, J., Nadal, M., Martí, E., Navalón-Madrigal, P., Schuhmacher, M., Domingo, J. L. (2012): Relationship between pollutant content and ecotoxicity of sewage sludges from Spanish wastewater treatment plants. - Science of the Total Environment 425: 99-109.

[20] Rosa, E. V. C., Giuradelliy, T. M., Corre^a, A. X. R., Rörig, L. R., Schwingel, P. R., Resgalla, C. Jr., Radetski, C. M. (2007): Ecotoxicological evaluation of the short term effects of fresh and stabilized textile sludges before application in forest soil restoration. Environ. Pollut. 146: 463-469.

[21] Salazar, M. J., Rodriguez, J. H., Nieto, G. L., Pignata, M. L. (2012): Effects of heavy metal concentrations $(\mathrm{Cd}, \mathrm{Zn}$ and $\mathrm{Pb})$ in agricultural soils near different emission sources on quality, accumulation and food safety in soybean [Glycine max (L.) Merrill]. - J. Hazard. Mater. 233-234: 244-253.

[22] STN 838303 (1999): Testing of dangerous properties of wastes. Ecotoxicity. Acute toxicity tests on aquatic organisms and 357 growth inhibition tests of algae and higher cultivated plants.

[23] STN EN 14735 (2006): Characterization of waste. Preparation of waste samples for ecotoxicity tests.

[24] Tukacs-Hájos, A., Szendefy, J., Maróti, G., Pap, B., Szabó, P., Rétfalvi, T. (2014): Monitoring of thermophilic adaptation of mesophilic anaerobe fermentation of sugar beet pressed pulp. - Bioresour. Technol. 166: 288-294.

[25] Tu, J. C., Zhao, Q. L., Wei, L. L., Yang, Q. Q. (2012): Heavy metal concentration and speciation of seven representative municipal sludges from wastewater treatment plants in Northeast China. - Environ. Monit. Assess. 184: 1645-1655.

[26] Ullman, J. L., Mukhtar, S. (2007): Impact of dairy housing practices on lagoon effluent characteristics: implications for nitrogen dynamics and salt accumulation. - Bioresour. Technol. 98: 745-752.

[27] Wahsha, M., Fontana, S., Nadimi-Goki, M., Bini, C. (2014): Potentially toxic elements in foodcrops (Triticum aestivum L., Zea mays L.) grown on contaminated soils. - Journal of Geochemical Exploration 147: 189-199.

[28] Wall, D. M., Allen, E., Straccialini, B., O'Kiely, P., Murphy, J. D. (2014): The effect of trace element addition to mono-digestion of grass silage at high organic loading rates. Biores. Technol., 172: 349-355.

[29] Walsh, G., Weber, D., Simon, T., Brashers, L. (1991): Toxicity test of effluents with marsh plants in water and sediment. - Environ. Toxicol. Chem.10: 517-525. 
[30] Walter, I., Martinez, F., Cala, V. (2006): Heavy metal speciation and phytotoxic effects of three representative sewage sludges for agricultural uses. - Environ. Pollut. 139: 507514.

[31] Young, B. J., Riera, N. I., Beily, M. E., Bres, P. A., Crespo, D. C., Ronco, A. E. (2012): Toxicity of the effluent from an anaerobic bioreactor treating cereal residues on Lactuca sativa. - Ecotox. Environ. Safe. 76: 182-186.

[32] Zhang, L., Jahng, D. (2012): Long-term anaerobic digestion of food waste stabilized by trace elements. - Waste Manage. 32: 1509-1515.

[33] Zhu, N. M., Li, Q., Guo, X. J., Zhang, H., Deng, Y. (2014): Sequential extraction of anaerobic digestate sludge for the determination of partitioning of heavy metals. Ecotox. Environ. Safe. 102: 18-24. 